\title{
Globalisation of the automotive industry: main features and trends
}

\section{Timothy J. Sturgeon}

Industrial Performance Center (IPC),

MIT, 292 Main Street (E38-104),

Cambridge, MA 02139, USA

E-mail: sturgeon@mit.edu

\section{Olga Memedovic*}

United Nations Industrial Development Organization,

Vienna International Centre,

A-1440 Vienna, Austria

E-mail: O.Memedovic@unido.org

*Corresponding Author

\section{Johannes Van Biesebroeck}

Department of Economics, University of Toronto,

150 St. George Street,

Toronto, Ontario M5S 3G7, Canada

E-mail: jovb@chass.utoronto.ca

\section{Gary Gereffi}

Department of Sociology,

Duke University,

Durham, NC 27708-0088, USA

E-mail: ggere@soc.duke.edu

\begin{abstract}
This paper lays out the main features of the global automotive industry and identifies several important trends. A boom in developing country sales and production has not yet overshadowed the importance of existing markets in developed regions. Regional integration is very strong at an operational level, yet the industry has recently developed a set of global-scale value chain linkages, and retains national and local elements as well. The paper highlights how global, regional, national and local value chains are nested to create a pattern of global integration that is distinctive to the industry. We use global value chain analysis to help explain the limits of build-to-order in the industry, the role of regional and global suppliers, the shifting geography of production and how the characteristics of value chain linkages in the industry favour tight integration and regional production. We describe how industry concentration focuses power in the hands of a few large lead firms and discuss the implications of this for value chain governance and the geography of production.
\end{abstract}

Keywords: globalisation; automotive industry; vehicle assembly and parts; GVC; global value chains. 
Reference to this paper should be made as follows: Sturgeon, T.J., Memedovic, O., Biesebroeck, J.V., Gereffi, G. (2009) 'Globalisation of the automotive industry: main features and trends', Int. J. Technological Learning, Innovation and Development, Vol. 2, Nos. 1/2, pp.7-24.

Biographical notes: Timothy J. Sturgeon is a Senior Research Affiliate at the Industrial Performance Center (IPC) at the Massachusetts Institute of Technology (MIT). He has a PhD in economic geography from U.C. Berkeley, and is Co-Organizer of the Global Value Chains Initiative (www.globalvaluechains.org). Tim served as Executive Director of the IPC's Globalization Study, and Globalization Research Director for the International Motor Vehicle Program at the Center for Technology, Policy and Industrial Development. His papers have appeared in international peer-reviewed journals including Industrial and Corporate Change, Review of International Political Economy, Journal of East Asian Studies, and Journal of Economic Geography, and as chapters in edited volumes, the most recent being, 'From commodity chains to value chains, interdisciplinary theory building in an age of globalization', in Jennifer Bair (Ed.): Frontiers of Commodity Chain Research, Stanford University Press, forthcoming, October 2008.

Johannes Van Biesebroeck is an Associate Professor of Economics at the University of Toronto and a Faculty Research Fellow at the National Bureau of Economic Research. His work on the automobile industry has been supported with grants by the Social Science and Humanities Research Council, the Canadian Foundation for Innovation, and the Ontario Innovation Trust and for his current research on supply chains he is a Network Researcher of AUTO21, the Canadian Network of Centers of Excellence, and of the International Motor Vehicle Program in Boston. He has served as a consultant on the automotive industry for Industry Canada and International Trade Canada, most recently investigating the potential impact of the Free Trade Agreement with South Korea. His papers on the automotive industry have appeared in international refereed journals like the Review of Economic Studies, the Journal of Applied Econometrics, Assembly Automation, and the Economic and Social Review.

Gary Gereffi is a Professor of Sociology and Director of the Center on Globalization, Governance \& Competitiveness at Duke University (http://www.cggc.duke.edu/), where he teaches courses in economic sociology, globalisation and comparative development, and international competitiveness. $\mathrm{He}$ received his BA degree from the University of Notre Dame and his $\mathrm{PhD}$ degree from Yale University. He has published six books and numerous articles on business-government relations in various parts of the world. His books include: Commodity Chains and Global Capitalism (Praeger Publishers, 1994); The Value of Value Chains: Spreading the Gains from Globalisation (special issue of the IDS Bulletin, Vol. 32, No. 3, July 2001); and Free Trade and Uneven Development: The North American Apparel Industry after NAFTA (Temple University Press, 2002) and The New Offshoring of Jobs and Global Development (International Institute of Labor Studies, 2006).

The views expressed herein are those of the author and do not necessarily reflect the views of the United Nations Industrial Development Organization.

\section{Introduction}

There are some features that the automotive industry shares with other globalised industries such as electronics, apparel and consumer goods and several that set it apart. The first common feature is that in all of these industries, including automotive, Foreign 
Direct Investment (FDI), global production and cross-border trade have accelerated dramatically since the late 1980s. Real and potential market growth and a huge surplus of low-cost but skilled labour in countries like Brazil, China and India have attracted large FDI flows to supply local markets and to export back to developed countries. The emergence of such global sourcing patterns has been facilitated and encouraged by trade and investment liberalisation through World Trade Organization (WTO) agreements.

The second common feature is increased outsourcing and the bundling of more value chain activities in supplier firms. As a result, developed country suppliers have increased their own involvement in FDI and trade, while developing country suppliers have increased their capabilities. The largest suppliers, all based in developed countries, have become 'global suppliers', with multinational operations and an ability to provide goods and services to a wide range of lead firms (Sturgeon and Lester, 2004).

The automotive industry is distinctive because of its extremely concentrated firm structure: a small number of giant companies exert an extraordinary amount of power over smaller firms. Eleven lead firms from three countries, Japan, Germany and the USA, dominate production in the main markets. The global scope of both lead firms and the largest suppliers was enhanced by a wave of mergers and acquisitions, and equity-based alliances in the 1990s. Lead firm concentration, though not as extreme as in some industries, such as commercial aircraft, has blunted efforts to establish the sort of industry-level technical and business process standards that prevail in less concentrated industries.

A second distinctive feature specific to the automotive industry is that final vehicle assembly, and by extension, parts production, has largely been kept close to end markets because of political sensitivities (discussed further in the text). Market saturation, high levels of motorisation and the tendency for automakers to 'build where they sell' have also encouraged the dispersion of final assembly, which now takes place in many more countries, than it did 30 years ago.

A third distinctive feature is its strong regional structure. Although the automotive industry has become more integrated globally since the mid-1980s, it has also developed strong regional-scale patterns of integration. In contrast, other important high-volume, consumer-oriented manufacturing industries, like apparel and electronics, have developed global-scale patterns of integration. ${ }^{1}$

A fourth distinctive feature of the automotive industry is that there are few fully generic parts or subsystems that can be used in a wide variety of end products without extensive customisation. Parts and sub-systems tend to be specific to particular vehicle models in contrast to memory chips and microprocessors in the electronics industry and to fabric and thread in the apparel industry. The absence of open, industry-wide standards undermines value chain modularity and ties suppliers to lead firms, limiting economies of scale in production and economies of scope in design. Suppliers are often the sole source for specific parts or module variants. This creates the need for close collaboration, raises the costs for suppliers that serve multiple customers and concentrates most design work into a few geographic clusters, typically near the headquarters of lead firms. Because value chain modularity is limited, linkages between lead firms and suppliers tend to be relational or captive in character.

A greater degree of global integration in the automotive industry has developed at the level of design, as global firms have sought to leverage design efforts across products sold in multiple end markets. The work of vehicle design and development continues to be concentrated in, or near, the headquarters of lead firms. In addition, suppliers of parts have taken on a larger role in design and have established their own design centres close 
to their major customers to facilitate collaboration. Because centrally designed vehicles are tailored to local markets and parts are manufactured in multiple regions to the degree possible, design activities and buyer-supplier relationships typically span multiple production regions. This has resulted in local, national and regional value chains in the automotive industry being 'nested' within the global organisational structures and business relationships of the largest firms, as shown in Figure 1.

Figure 1 The nested geographic and organizational structure of the automotive industry

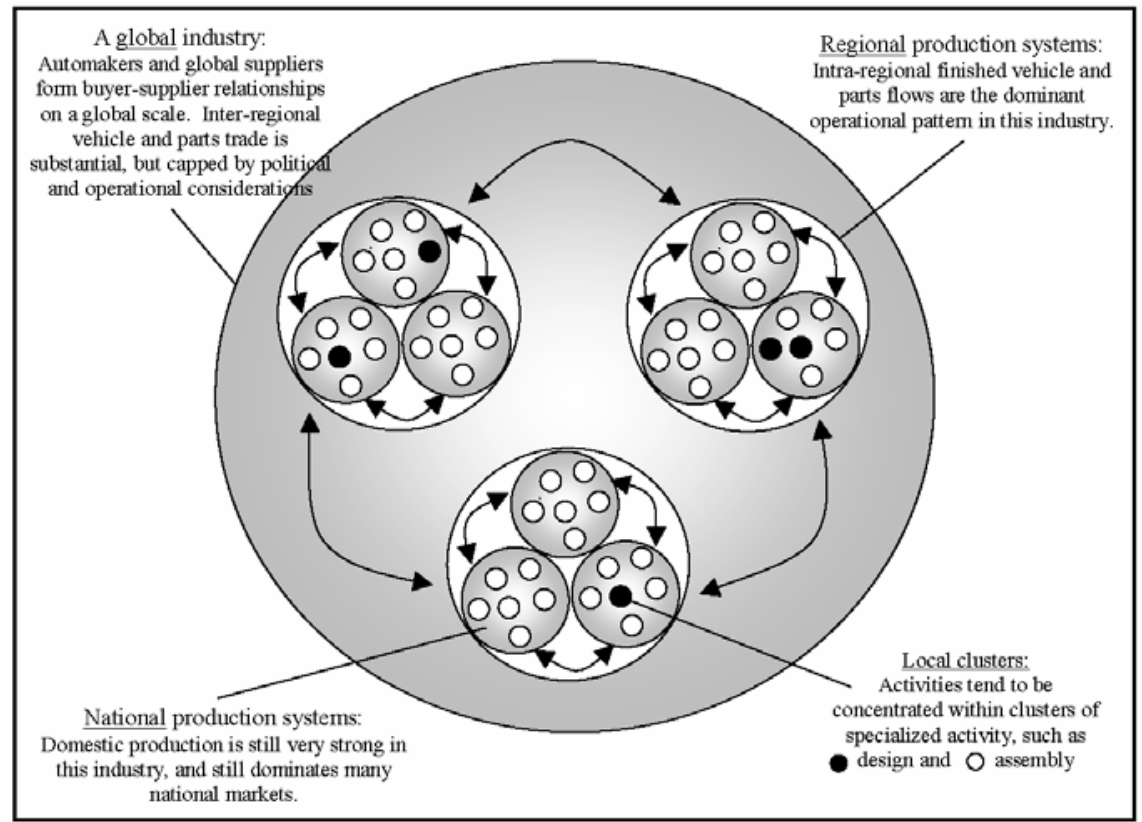

Source: Sturgeon; Van Biesebroeck and Gereffi (2007)

\section{Main trends}

\subsection{The boom in vehicle production in the 1990s and 2000s}

Global vehicle production has more than doubled since 1975, from 33 to nearly 73 million in 2007 (see Figure 2 and Tables 1, 2 and 3 below). The opening of new markets in China and India has helped to drive the pace of growth. While seven countries accounted for about $80 \%$ of world production in 1975, 11 countries accounted for the same share in 2005.

As Figure 2 illustrates, world vehicle production grew at an annual average rate of around $2 \%$ in the period $1975-1990$, rising to around 3\% in 1990-2005. Low rates of motorisation and huge populations resulted in a surge of new investment in China and India, where market growth - and, accordingly, production - has been increasing very rapidly (see Table 1). In this context, the ability to increase or maintain their share of global automotive production since the entry of China and India in 1990-2005 can be seen as a real success for some countries. Canada, for example, has maintained its share of $4 \%$ in 2005. 
Figure 2 The geographic dispersal of vehicle production, 1975-2005 (see online version for colours)
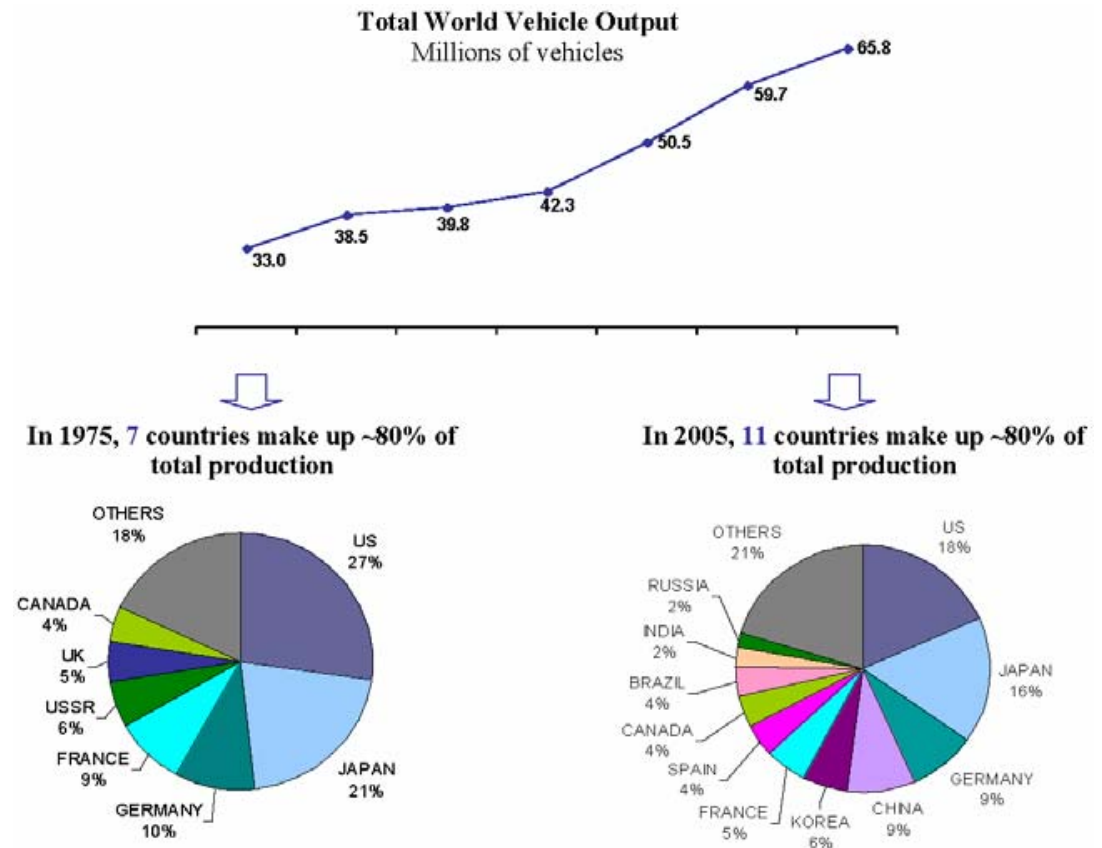

Notes: Includes cars and trucks but not large trucks and buses as in Table 1.

Source: Automotive News Market Data Books

Table 1 Motor vehicle production, selected countries, 1996-2006, in 000 units and in \% for growth rate in ' 000 units and in percentages

\begin{tabular}{lccccccc}
\hline & 1996 & 1998 & 2000 & 2002 & 2004 & 2006 & $\begin{array}{c}\text { Growth } \\
\text { rate (\%) }\end{array}$ \\
\hline China & 1,240 & 1,628 & 2,009 & 3,251 & 5,071 & 7,272 & 19.3 \\
India & 541 & 535 & 867 & 892 & 1,511 & 1,876 & 13.2 \\
Republic of Korea & 2,354 & 1,787 & 2,858 & 3,148 & 3,469 & 3,840 & 5.0 \\
France & 2,359 & 2,923 & 3,352 & 3,693 & 3,666 & 3,164 & 3.0 \\
Brazil & 1,813 & 1,547 & 1,671 & 1,793 & 2,210 & 2,597 & 3.6 \\
Mexico & 1,222 & 1,460 & 1,923 & 1,805 & 1,555 & 2,043 & 5.3 \\
Russian Federation & 1,029 & 1,021 & 1,203 & 1,220 & 1,388 & 1,495 & 3.8 \\
Germany & 4,843 & 5,727 & 5,527 & 5,145 & 5,570 & 5,818 & 1.8 \\
Spain & 2,412 & 2,826 & 3,033 & 2,855 & 3,012 & 2,776 & 1.4 \\
Canada & 2,397 & 2,570 & 2,962 & 2,629 & 2,712 & 2,544 & 0.6 \\
Japan & 10,346 & 10,050 & 10,141 & 10,258 & 10,512 & 11,484 & 1.0 \\
United States & 11,832 & 12,003 & 12,774 & 12,280 & 11,988 & 11,351 & -0.4 \\
United Kingdom & 1,924 & 1,976 & 1,814 & 1,821 & 1,856 & 1,650 & -1.5 \\
Italy & 1,545 & 1,693 & 1,738 & 1,427 & 1,142 & 1,212 & -2.4 \\
\hline
\end{tabular}

${ }^{\mathrm{a} C}$ Compound Annual Growth Rate (CAGR).

Note: the relative positions of Russia and Canada differ from those in Figure 2 because Table 1 includes all vehicles including large trucks and buses.

Source: Ward's Automotive Yearbook, various years 
Much of this global growth in the industry was result of growth in the emerging markets in Asia (mainly China, the Republic of Korea and India), Latin America (mainly Mexico and Brazil) and Eastern Europe (mainly the Russian Federation), as illustrated by Table 1. Although the share of the Triad (USA and Canada, Japan, European Union) of global vehicle production decreased over the period $1997-2007$, from $77 \%$ to $50 \%$, it still accounted for the lion's share of global vehicle production in 2007 (Table 2).

Table 2 Unit production of all motor vehicles by country and region, 1997 and 2007 ('000s and in \%)

\begin{tabular}{|c|c|c|c|c|c|c|}
\hline Country or region & 1997 & 2003 & 2007 & $1997(\%)$ & $2003(\%)$ & $2007(\%)$ \\
\hline Europe & 17,889 & 20,004 & 22,754 & 33.7 & 33.0 & 31.0 \\
\hline EU & 15,313 & $16,778^{\mathrm{b}}$ & $19,697^{\mathrm{c}}$ & 28.8 & 27.7 & 27.0 \\
\hline Turkey & 344 & 534 & 988 & 0.6 & 0.9 & 1.4 \\
\hline Eastern Europe & 2,231 & 2,689 & 1,958 & 4.2 & 4.4 & 2.7 \\
\hline Russian Federation & 1160 & 1280 & 1,948 & 2.2 & 2.1 & 2.7 \\
\hline NAFTA & 15,746 & 16,210 & 15,454 & 29.6 & 26.7 & 21.1 \\
\hline South America & 2,516 & 2,037 & 3,684 & 4.7 & 3.4 & 5.0 \\
\hline ASIA-Oceania & 16,965 & 21,971 & 30,672 & 31.9 & 36.2 & 42.0 \\
\hline Africa & $359^{\mathrm{a}}$ & 396 & 564 & 0.7 & 0.6 & 0.8 \\
\hline $\begin{array}{l}\text { Triad regions (USA, } \\
\text { Canada, Japan, EU) }\end{array}$ & 40,674 & 41,731 & 36,552 & 76.6 & 68.8 & 50.0 \\
\hline World Total & 53,117 & 60,633 & 73,102 & 100 & 100 & 100 \\
\hline
\end{tabular}

${ }^{\mathrm{a}}$ Data for 1998.

${ }^{\mathrm{b}}$ Data for EU 15 countries.

${ }^{\mathrm{c}}$ Data for EU 27 countries.

Source: Production data estimates from OICA (Organisation Internationale des

Constructeurs d'Automobiles, (www.oica.net: visited on 16-05-2008)

$=$ International Organization of Motor Vehicle Manufacturers

From a geographic point of view, the world automotive industry is in the midst of a profound transition. Since the mid-1980s, it has, like many other industries, been shifting from a series of discrete national industries to a more integrated global industry. Global integration embeds firms in larger regional and global-scale systems of production, consumption, innovation, sourcing, command and control. These global ties have been accompanied by strong regional structures at the operational level. Market differences sometimes require automakers to alter the design of their vehicles to fit the characteristics of specific markets (e.g., right vs. left hand drive, more rugged suspension and larger fuel tanks for developing countries, pick-up trucks for Thailand and Australia, etc.). While many vehicles are designed with global markets in mind, an increasing number are developed with inputs from affiliated regional design centres, where designers and engineers help to tailor vehicles to national and regional markets.

\subsection{The continuing importance of core markets}

Over the last decade, leading vehicle manufacturers have extended their reach, producing and selling vehicles in an increasing number of markets. Nevertheless, for many companies the home market remains important. 
Production and sales by the leading companies in Europe and North America remained concentrated in their home regions (Table 3). In 1997, GM, Ford, VW and Fiat sold on an average $63 \%$ of their vehicles in their home markets $(63 \%, 64 \%, 59 \%$ and $66 \%$, respectively): in 2006 , the average was $55 \%$. In 2006 , production concentration increased for VW and decreased for all other companies.

Table 3 Production and sales of motor vehicles in home region by company in 1997 and 2006

\begin{tabular}{|c|c|c|c|c|c|}
\hline & & $\begin{array}{l}\text { Region's share } \\
\text { in global } \\
\text { production (\%) }\end{array}$ & $\begin{array}{l}\text { Region's share } \\
\text { in global } \\
\text { production (\%) }\end{array}$ & $\begin{array}{l}\text { Regional sales } \\
\text { share in global } \\
\text { sales }\end{array}$ & $\begin{array}{c}\text { Region's share } \\
\text { in global sales } \\
(\%)\end{array}$ \\
\hline Company & Region & $1997^{\mathrm{a}}$ & 2006 & 1997 & 2006 \\
\hline General Motors & America $^{\mathrm{b}}$ & 69 & 50 & 63 & 54 \\
\hline Ford & America $^{\mathrm{b}}$ & 67 & 43 & 64 & 55 \\
\hline DaimlerChrysler & America $^{\mathrm{b}}$ & & 58 & & 58 \\
\hline Renault & Europe & 97 & 75 & 93 & 62 \\
\hline PSA & Europe & 85 & 70 & 84 & 62 \\
\hline Volkswagen Group & Europe & 62 & 66 & 59 & 56 \\
\hline Fiat & Europe & 60 & 55 & 66 & 53 \\
\hline Toyota & Japan & 73 & 56 & 43 & 26 \\
\hline Nissan & Japan & 62 & 41 & 42 & 22 \\
\hline Honda & Japan & 57 & 37 & 36 & 20 \\
\hline
\end{tabular}

${ }^{\mathrm{a}}$ Data for 1997 refer to Western Europe.

${ }^{\mathrm{b}}$ Data for 2005.

Sources: OICA 2007 (www.oica.net), 2007: data for 2005: Global Insight, as cited in

Standard and Poors Automobile Industry Survey

(http://www.duke.edu/web/soc142/team1/references.html\#1)

The global and regional distribution of vehicle production and sales for the leading companies, depicted in Table 3, clearly shows that the concentration of production and sales in home locations is changing only slowly. The exceptions are Japanese producers, which experienced the largest fall in concentration in the home market. Honda produced $57 \%$ of its global production in its home market in 1997 and 37\% in 2006; and made 36\% of its sales in its home market in 1997 and 20\% in 2006. Production concentration increased for VW group while its sales concentration did not change much. The French producers, Peugeot and Citroen SA (PSA) and Renault, had the highest concentration in production and sales in both years, reflecting slow diversification of production and sales in other markets of the world. The decrease in concentration in production and sales of Japanese producers reflects their successful market penetration in Europe (mainly by Nissan) and North America (by Nissan, Honda and Toyota).

\subsection{Regional integration of production}

On the production side, the dominant trend is towards regional integration, a pattern that has been intensifying since the mid-1980s. Automakers and large suppliers of vehicle parts are deeply engaged in multiple regional production systems. In North and South America, Europe, Southern Africa and Asia, regional parts production tends to feed final assembly plants that produce finished vehicles for regional markets. Within 
regions, there is a gradual shift in investment towards locations with lower operating costs: the south of the USA and Mexico in North America; Spain and Eastern Europe in Europe; and South East Asia and China in Asia.

Several factors contribute to the importance of regional production in the automotive industry. Some have a political and strategic dimension, while others arise from cultural, technical and economic factors. The high cost and the visibility of automotive products, especially passenger vehicles, can provoke political backlash among the general population if imported vehicles account for too large a share of vehicles sold and when local producers are threatened by imports. More importantly, powerful local lead firms and industry associations, large-scale employment and relatively high rates of unionisation increase the political influence of the automotive industry in many countries. So even where import tariffs and local content rules are not present or are scheduled to decline under WTO rules, assemblers have chosen to restrict exports 'voluntarily' and set up local production units to forestall political backlash. This explains why automakers from Japan, Germany and Republic of Korea with plants in North America have not concentrated their production in Mexico and Canada, even though these countries have lower operating costs and preferential market access to the USA because of the North American Free Trade Agreement (NAFTA), enacted in 1994. Volkswagen is the exception in that it has concentrated all of its North American production in Puebla, Mexico.

There are other reasons, more technical and economic in nature, to keep production close to final markets. First, motor vehicles and many of their main parts, such as seats, engines, transmissions and body panels, are large, heavy and sometimes fragile, which increase transportation costs. Second, the industry-wide implementations of 'lean' production techniques and increasing product and module variety since the mid-1980s have kept parts production close to final assembly. Just-in-Time (JIT) parts deliveries that keep working inventories low and reveal defects quickly are an important element of lean production. But JIT parts deliveries do not always require side-by-side co-location of parts and final assembly plants. Lean work-in-progress inventories can be achieved within large continental regions with reliable road and rail systems, and developed logistics capabilities, such as in North America and Western Europe. Longer lead times and greater irregularities in trans-continental oceanic shipping have so far limited truly global sourcing. Again, the bulky character of many auto parts precludes the option of airfreight. In the electronics industry, in contrast, the light weight of components enables greater implementation of lean production at the global level. The tendency to build vehicles and major, heavyweight subsystems close to end markets can be traced back to the earliest days of the automotive industry (Sturgeon and Florida, 2000), but the picture has become more complex as new markets have emerged and the industry has become more globally integrated.

\subsection{National and local elements}

Despite intensifying regional integration, the automotive industry retains several national and local elements. Consumer tastes and purchasing power, driving conditions, labour markets regulations, standard requirements and public policy (incentives and taxation) can vary widely by country (and even within countries). Consumers in high-income countries are more demanding and require specific features, even for small cars. Consumer preferences also reflect the characteristics of particular societies and are the result of path dependence. 
Roads and fuel are frequently of poorer quality in developing than in developed countries, requiring vehicles to be adapted to local conditions, particularly by strengthening the body, suspension, steering, etc. Each market has its own set of regulations (environmental: water regulations, air emissions, waste management, environmental clean up; noise control, fuel economy) with which automakers have to comply. Compliance with such regulations has a big impact on price and performance. Taxation policies can create demand for specific cars, for example small and cheaper vehicles in Brazil and light pick-up trucks in the case of Thailand (Humphrey and Memedovic, 2003).

Within countries, automotive production (and employment) is typically clustered in one or a few industrial regions. In some cases these clusters specialise in specific aspects of the business, like vehicle design, final assembly, or the manufacture of parts that share a common characteristic, like electronic content or labour intensity. Because of high investment in long-lived capital equipment and skills and the tight linkages between value chain activities mentioned earlier, the geography of automotive clusters tends to be long-lived.

Recent research (Reichhart and Holweg, 2008) also points to the increasing co-location of highly dedicated supplier clusters, or local dedicated units, near automaker assembly plants. In Spain, such 'supplier parks' emerged in 1992 near the Seat assembly plant in Abrera and then gained popularity at other locations, for instance in Bratislava, Slovakia for Skoda-VW; in Cologne, Germany for Ford; in Curitiba, Brazil for Renault; and in North America (in Chicago, Ford and Puebla and in Mexico) for VW. Within such parks, production facilities, typically owned by global suppliers, are dedicated to supplying a single customer. The supplier park model is typical for components with high logistics costs that include large, delicate and bulky built-up modules, like dash boards and finished seats, or for parts that need to be delivered to final assembly lines on a JIT basis, like those that require sequential delivery to the line based on colour or model variation. Such requirements give suppliers only a few hours to react to the request for delivery of the module. In addition, JIT delivery allows suppliers to maintain low levels if in process and finished inventory, which acts as a buffer against delivery and quality problems. Thus supplier parks have become an important complement to (and enabler of) global sourcing strategies aimed at minimising the total cost for each component. However, their suitability is not universal. It depends on the characteristics of specific components and the characteristics of demand, i.e. product variety and volume. Establishing units in multiple supplier parks is expensive and duplicative. As a result, suppliers sometimes rent facilities from automakers or local government authorities to lessen these costs and loosen the level of dependence on the automaker. They also may use supplier park facilities to hold, or make superficial changes to inventory produced elsewhere.

Logistics operations (inbound and outbound) in the automotive supply chain are complex and account for large expenses and therefore are segments in the value chain where improvements can be made. Better coordination between inbound and outbound logistics contributes to optimising the supply chains, to reducing inventories and to responding to consumer requests. As economies grow, the competition shifts towards brand image and customisation and here the speed and reliability of logistics operations becomes a critical elements. One implication of this development is the growing proliferation of supplier parks, whereby logistics firms effectively 'bridge the geographical distance' (Reichhart and Holweg, 2008, see below). Most emerging economies have a poor logistics infrastructure, which can hurt their export competitiveness in the long term and the automotive industry's commitment to reducing $\mathrm{CO} 2$ emission from traffic. ${ }^{2}$ 


\section{Global value chains in the automotive industry}

Global Value Chain (GVC) analysis typically begins by dividing industries into two broad types of firms: lead firms and suppliers. Lead firms decide product strategy, place orders and take financial responsibility for final goods production. Accordingly, our GVC analysis of the automotive industry focuses on the vehicle assembly and parts sectors (see Figure 3). This emphasis on design and production activities is justified because these are the segments of the chain that can be easily separated from end markets, unlike retail sales and after-sales service. ${ }^{3}$

Figure 3 A simple automotive value chain

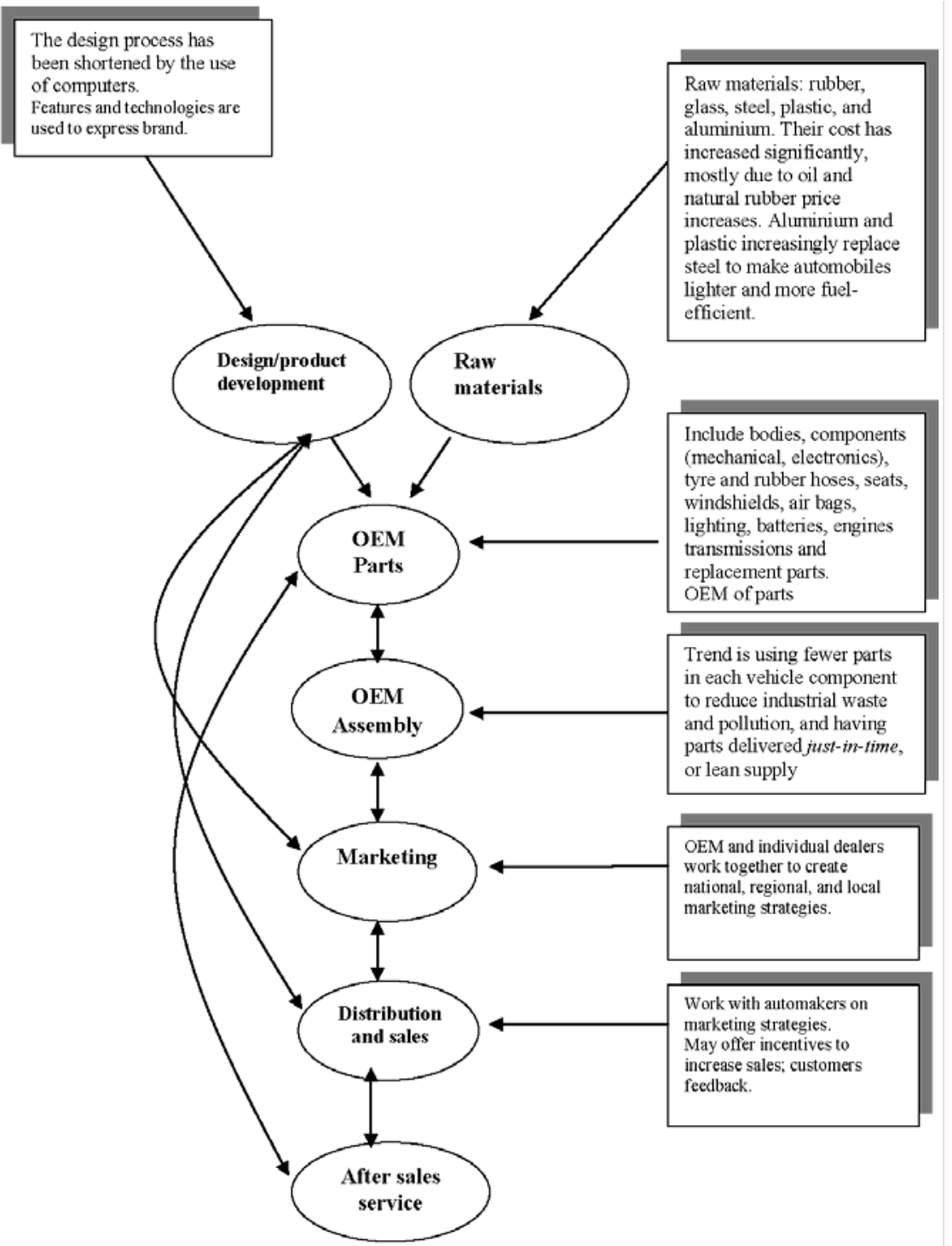

Source: Memedovic, 2007 
Lead firms in the automotive industry, known as automakers or original equipment manufacturers, carry out most aspects of product design, the production of most engines and transmissions and nearly all vehicle assembly within their own facilities. They are large employers, traders and innovators. They have substantial coordination and buying power in the chain. In GVC parlance, automotive industry value chains are producerdriven (Gereffi, 2005). But, since the early 1990s, outsourcing has led to the creation of large global suppliers, which have taken on a more extensive role in the areas of design, production and foreign investment. The largest 20-30 suppliers have shifted the balance of power away from leading automakers, although in a very partial and incomplete way.

\subsection{The failure of 'build to forecast'}

Intensified global competition has led automakers to attempt to institute a 'build-to-order' approach to fulfillment, in which consumers are able to define the characteristics of the vehicles before they are produced. In the more traditional and still prevalent 'build-to-forecast' approach, production is based on forecast demand and information received from dealers about prior sales. Recent industry analysts show a rise of auto body styles, colours and options, suggesting that build-to-order is taking hold. In Germany, $62 \%$ of cars sold are built-to-order, the highest share of all the major markets. Even so, lead times are long and consumer choices can be quite superficial and limited. As a result, $24 \%$ of German car buyers indicated that they felt that they had compromised on their vehicle's specifications (Holweg and Pil, 2004).

Implementation of the 'build-to-forecast' approach was historically driven by production technology and the limited adoption of build-to-order is no different. Large economies of scale are dictated by moving assembly lines with dedicated fixtures and the use of highly integrated pressed-steel monocoque bodies (Figure 4, left loop), ${ }^{4}$ while long lead times for custom-built vehicles distorts demand information (right loop).

Figure 4 The vicious cycles of make-to-forecast (see online version for colours)

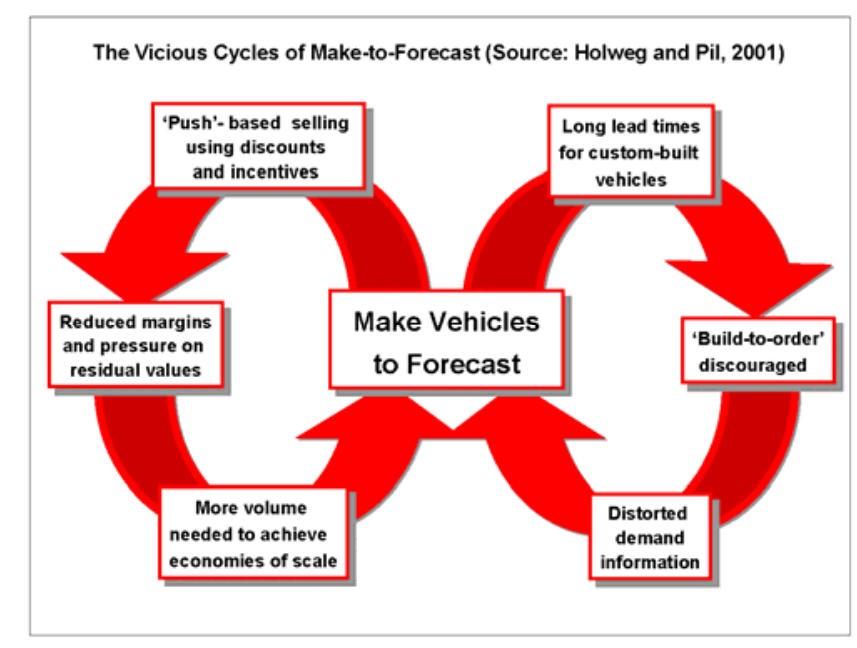

Source: Holweg and Pil (2001)

The time from order to delivery takes on an average of 40 days, of which only $60 \mathrm{~h}$ is used for production; $85 \%$ of the time is accounted for by scheduling and parts sequencing requirements, rather than on the physical product flow (see Figure 5). 
Figure 5 Time Delays in the Order Fulfilment Process (see online version for colours)

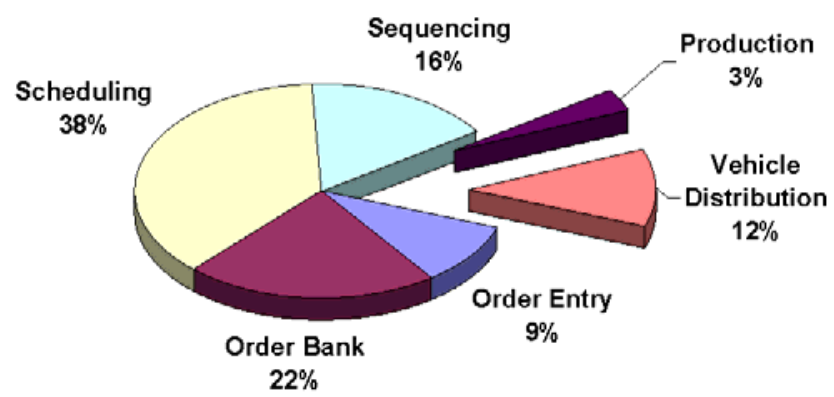

Source: Holweg and Pil (2004)

As a result, very little has changed regarding how manufacturers plan their production and operate their distribution networks. Consumers remain largely decoupled from the vehicle production process, large inventories exist in the distribution system and dealers continue to rely on rebates and steep discounts to sell vehicles that do not fit consumer desires.

\subsection{The new global supply base}

Globalisation has created two classes of suppliers in the automotive industry, global and local. In the past, lead firms either exported parts to offshore assembly plants or relied on local suppliers in each production location. Today, a new class of supplier has been added, the global supplier (Sturgeon and Lester, 2004). This trend has expanded the field of customers for many large suppliers to the automotive industry. Most of the top suppliers now serve US, European and Japanese lead firms and have had to adapt to the different approaches these firms take to vehicle development and to forming and maintaining supplier linkages. Lead firm globalisation has also meant globalisation for suppliers, as demands for local production are now often part of winning contracts. Managers from three different suppliers put it as follows during interviews with Industrial Performance Center researchers in 2000 and 2002

The industry began to change 5-10 years ago. Today it is a requirement to serve platforms - it is part of the bid. If a supplier doesn't have a global strategy, it can't bid. New projects are no longer seen as an opportunity to expand globally - instead, a supplier must have a global base in place to even make a bid. This forces suppliers to have a global supply system in place.

Suppliers must support assemblers as a sole source for global products lines to support 'commonisation'. We must supply the same part, with the same quality and price, in every location. If [the automaker] says to go to Argentina, we must go or lose existing, not just potential, business. Logistics are becoming a key competitive advantage; we must have the ability to move production to where customer's facilities are.

We want our plants to be present where vehicles are produced. Sometimes customers ask us to locate near offshore assembly plants to provide local content ... We will follow our customer's strategy by establishing local engineering operations in large emerging markets only, such as Republic of Korea, Mexico and Brazil.

Nevertheless, full production is not required at each location. Suppliers with a global presence can concentrate volume production of specific components in one or a few 
locations and ship them to plants close to their customer's final assembly plants where modules and sub-systems are built up and sent to the final assembly line as needed.

\subsection{A concentrated industry structure gives power to a few giant firms}

Extremely concentrated firm structure in the industry creates high barriers to entry and limits the upgrading prospects for smaller firms. A new vehicle design typically requires more than 30,000 engineering hours, takes 3-5 years to complete and needs several billion dollars of up-front investment. Design requirements and specifications for parts come from the top down. Concentration at the top of the value chain allows each lead firm to create its own standards and specifications, driving up transaction costs for suppliers and making investment in information technology and production equipment more customer-specific. It also creates a top-heavy structure of innovation that leaves little room for smaller firms to improve their prospects by seeking new customers or by developing their own unique products and technologies. ${ }^{5}$

In 2001, 11 lead companies from three countries, Japan, Germany and USA, produced more than 2.4 million vehicles each and together accounted for around $82 \%$ of world vehicle production (Table 4). In 2006, the situation had not changed much: 12 companies produced more than 2 million vehicles each and together accounted for $75 \%$ of world vehicle production.

Table 4 Vehicle production by company, 2001, 2003 and 2006

\begin{tabular}{|c|c|c|c|c|c|c|}
\hline & $\begin{array}{c}\text { Production } \\
\text { (units) }\end{array}$ & $\begin{array}{c}\text { Production } \\
\text { (units) }\end{array}$ & $\begin{array}{c}\text { Production } \\
\text { (units) }\end{array}$ & $\begin{array}{c}\text { Share of } \\
\text { global } \\
\text { production }\end{array}$ & $\begin{array}{c}\text { Share of } \\
\text { global } \\
\text { production } \\
(\%)\end{array}$ & $\begin{array}{c}\text { Share of } \\
\text { global } \\
\text { production } \\
(\%)\end{array}$ \\
\hline Company & $\begin{array}{c}2001 \\
(000000)\end{array}$ & $\begin{array}{c}2003 \\
(000000)\end{array}$ & $\begin{array}{c}2006 \\
(000000)\end{array}$ & $\begin{array}{c}2001 \\
(\%)\end{array}$ & $\begin{array}{c}2003 \\
(\%)\end{array}$ & $\begin{array}{c}2006 \\
(\%)\end{array}$ \\
\hline General Motors & 7.6 & $8.2^{\mathrm{a}}$ & 8.9 & 13.6 & 13.8 & 13.0 \\
\hline Toyota & 6.0 & 6.2 & 8.0 & 10.8 & 10.4 & 11.7 \\
\hline Ford & 6.7 & $6.6^{\mathrm{b}}$ & 6.3 & 12.0 & 11.0 & 9.0 \\
\hline Volkswagen Group & 5.1 & 5.0 & 5.7 & 9.2 & 8.4 & 8.4 \\
\hline Honda & 2.7 & 2.9 & 3.7 & 4.9 & 4.9 & 5.4 \\
\hline PSA Group & $3.1^{\mathrm{c}}$ & 3.3 & 3.4 & 5.6 & 5.6 & 5.0 \\
\hline Nissan & 2.6 & 2.9 & 3.2 & 4.7 & 4.9 & 4.7 \\
\hline Chrysler & & & 2.5 & & & 3.7 \\
\hline Hyundai & 2.5 & 2.7 & 2.5 & 4.5 & 4.5 & 3.7 \\
\hline Renault & 2.4 & 2.4 & 2.5 & 4.3 & 4.0 & 3.7 \\
\hline Fiat & 2.4 & 2.0 & 2.3 & 4.3 & 3.4 & 3.4 \\
\hline DaimlerChrysler & 4.4 & 4.2 & 2.0 & 7.9 & 7.0 & 2.9 \\
\hline Total of above & 45.5 & 46.4 & 51.0 & 81.8 & 78.0 & 74.7 \\
\hline Other manufacturers & 10.1 & 13.1 & 17.3 & & & \\
\hline Total & 55.6 & 59.5 & 68.3 & & & \\
\hline
\end{tabular}

${ }^{\mathrm{a}}+$ Opel- Vauxhal.

${ }^{\mathrm{b}}$ Includes Jaguar \& Volvo.

${ }^{\mathrm{c}}$ Includes PSA Group, Peugeot and Citroen SA.

Source: OICA (Organisation Internationale des Constructeurs d'Automobiles, (www.oica.net), 2007 


\subsection{Value chain linkages in the automotive industry}

Since there are few standardised parts in the automotive industry, specifications must be developed for every part of each vehicle model. Lead firms have been trying to decrease the design effort required by sharing vehicle 'platforms' across a family of vehicle models. Platforms generally include rolling chassis and sometimes braking systems, suspension parts, engines and transmissions. But there are limits to the degree that parts can be shared. First, platforms are generally shared only across the brands owned by a specific lead firm. For example, some Ford's and Jaguar's (which is owned by Ford) models share a basic platform. Second, to avoid product homogenisation and to achieve performance goals, most parts that are visible to consumers and many that are not, remain model-specific. Vehicle performance characteristics such as noise, vibration and handing are deeply interrelated and it is difficult to quantify their interactions in advance. As a result, it has proved impossible for vehicle designers to achieve specific performance goals using standardised parts and both design and value chain modularity have limited application in the automotive industry.

The lack of standardisation, the importance of systems integration for the performance of vehicles, and the complexity of many vehicle parts and sub-systems help to structure how value chain linkages are forged and managed in the automotive industry. Specifications can either be developed jointly, in a co-design process, or suppliers must be provided with full instructions on what to produce. In the first, more relational approach, design engineers from lead firms and suppliers work closely together to develop parts that will work in the context of the overall vehicle design. In the second instance, lead firm engineers develop all vehicle parts in-house and then put the part out for bids, creating a classic market linkage with suppliers, or, when relationship-specific investments by suppliers are required, which they often are, captive linkages. Market linkages allow for the easy switching of suppliers, while relational and captive linkages make supplier switching more difficult.

Historically, European and US lead firms have sought to maintain market linkages with suppliers. However, the acceleration of outsourcing in the 1990s bundled more value chain functions in supplier firms, increasing the need for co-design. As Herrigel (2004) shows, this has created deep tensions in the automotive industry, especially in the relationship between the Big 2 lead firms (General Motors and Ford) and their largest suppliers. The Big 2 have a long history of extremely aggressive buying practices, pitting suppliers against each other to achieve lower input costs and switching suppliers with little advance notice.

While these practices have not changed, they have become much more problematic as linkages with suppliers have become more relational. Switching the sourcing of a part, or a module or sub-system consisting of many parts, from a supplier that engaged in co-design to a supplier that did not, is possible once the specifications have been fully developed and have stabilised in the context of high volume production, but the cooperative relationships that may have built up are shattered. Especially relevant is the fact that suppliers are often not fully paid for their design services, but are expected to provide them as part of winning the initial contract. The result is an oscillation between relational linkages, driven by the engineering requirements of vehicle development in the context of increased outsourcing, and market linkages, which are reverted to when lead firms put co-developed parts, modules and sub-systems out for open re-bid after a year or so of production in an effort to lower input costs. For large suppliers, the costs of 
these purchasing practices are extremely high. In fact, the high cost of design and the lack of compensation for the design services they provide, along with the aggressive and non-cooperative purchasing practices of the Big 2, may have been one of the factors contributing to a recent spate of bankruptcies among large automotive suppliers (see Figure 6).

Japanese lead firms in the automotive industry generally pursue a different approach. While co-design with suppliers has been limited in scope, Japanese lead firms have tended to form long-term, paternalistic captive relationships with suppliers. This has often involved equity ties between automakers and suppliers, which respond by dedicating themselves to serving their largest customer. In addition, the need for co-design is less because Japanese automakers have kept the design and parts and subsystems almost entirely in-house. Nevertheless, supplier switching without notice, exclusively to reap a short-term gain, is almost unheardof, and long-term trust-based relationships are allowed to develop. It is notable that no Japanese suppliers are shown in Figure 6.

Figure 6 Major automotive supplier bankruptcies, 1 January 1999 - 10 February 2008 (see online version for colours)

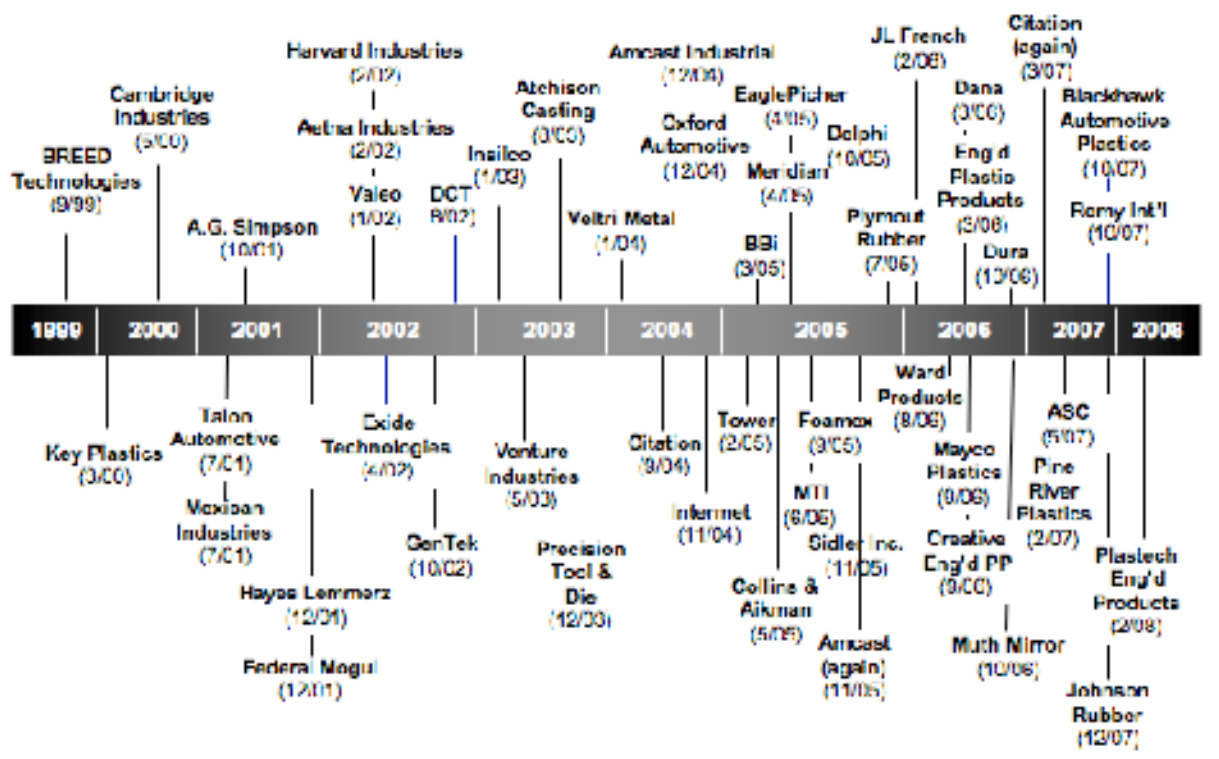

Source: Korth (2006/2008), IRN Inc.

The different approaches that automakers from different home countries take toward supplier relationships was described by the managers of a US-based supplier in an interview with researchers from the Industrial Performance Center at MIT in 2000 as follows: ${ }^{6}$

There is some truth to the idea of that some assemblers are more loyal to their suppliers than others-Japanese assemblers are the most loyal, followed by Europeans. Americans are the least loyal. The Japanese transplants set high hurdles, but the expectation is for long-term business and that problems will be fixed. 
Regardless of how supplier relationships are managed, lead firms have a huge amount of power in the chain. This has increased with lead firm consolidation

\section{Conclusion}

This paper highlights several features that set the automotive industry apart from other global goods-producing industries, such as electronics and apparel. The automotive industry is similar to these others in that the geographic scope of lead firms and their largest suppliers expanded in a wave of offshore investments, mergers, acquisitions, and equity-based alliances in the 1990s. In industry after industry, giant firms have arisen in many vertical segments of the value chain, and these firms are building relationships with one another at the global level (Sturgeon and Lester, 2004).

The automotive industry, especially firms based in the United States, embraced outsourcing without a robust set of industry standards in place for specifying the technical characteristics of products and processes. To some extent this reflects the difficulty of codifying tacit knowledge about mechanical processes but it also reflects the strong competition between a tight oligopoly of very powerful lead firms unwilling to work together to develop robust industry-level standards. Because parts and sub-systems tend to be specific to vehicle platforms and models, suppliers have been forced to interact closely with lead firms, which has driven up transaction costs and limited the economies of scale in production and economies of scope in design afforded by value chain modularity. The different approaches that lead firms have taken toward solving such GVC governance challenges have helped to shape competitive outcomes, for lead firms and for the supply base as a whole.

In the automotive industry, technical necessity, political sensitivities and market variation have kept final vehicle assembly, and by extension much of parts production, close to end markets. Powerful lead firms and industry associations, large-scale employment and relatively high rates of unionisation, and the iconic status of motor vehicles in the minds of consumers (and policy-makers) in many countries increase the political clout of the automotive industry. So even where import tariffs and local content rules are not present or are scheduled to decline under WTO rules, foreign assemblers have chosen to 'voluntarily' restrict exports and set up local production to forestall political backlash. As a result, regional and national production structures remain surprisingly strong and coherent in comparison to other volume good producing industries where global sourcing of parts and materials is the norm and worldwide demand for finished goods can be met from a handful of giant production clusters. As a result, political pressures go a long way toward explaining patterns of direct investment in the automotive industry.

The economic geography of the automotive industry is playing out differently in different segments of the value chain. We see the concentration of design engineering in existing clusters, dispersal of some conceptual design to gain access to 'lead users' regional integration of production, and global sourcing for some categories of parts. In all instances, however, it is automakers that drive location patterns; the influence that lead firms have on the economic geography of the industry is rooted in their enormous buying power. 


\section{Acknowledgement}

We are grateful to Matthias Holweg for reviewing some parts of this paper.

\section{References}

Berger, S. and the MIT Industrial Performance Center (2005) How We Compete, Doubleday, New York.

Gereffi, G. (2005) 'The global economy: organization, governance and development', in Smelser, N. and Swedberg, R. (Eds): Handbook of Economic Sociology, Princeton University Press and Russel Sage Foundation.

Gereffi, G. (2006) The New Offshoring of Jobs and Global Development, International Institute for Labor Studies, Geneva.

Helper, S. (2000) 'Economists and field research: you can observe a lot just by watching', The American Economic Review, Papers and Proceedings of the 112th Annual Meeting of the American Economic Association, Vol. 90, No. 2, pp.228-232.

Herrigel, G. (2004, March/June) 'Emerging strategies and forms of governance in high-wage component manufacturing regions', Industry and Innovation Vol. 11, Nos. 1/2, pp.45-79.

Holweg, M. and Pil, F.K. (2001) 'Successful build-to-order strategies start with the customer', MIT Sloan Management Review, Vol. 43, No. 1, pp.74-83.

Holweg, M. and Pil, F.K. (2004) The second century: reconnecting customer and value chain through build-to-order, MIT Press, Cambridge, MA.

Humphrey, J. and Memedovic O. (2003) 'The global automotive industry value chain: what prospects for upgrading by developing countries?' sectoral studies series, United Nations Industrial Development Organization, Vienna.

Memedovic, O. (2007) Presentation Prepared for the UNCTAD Expert Group Meeting on Enhancing the Participation of Small and Medium-Sized Enterprises into Global Value Chins, Held on 18-19 October 2007, in Geneva.

Reichhart, A. and Holweg, M. (2008) 'Co-located supplier clusters: forms, functions, and theoretical perspectives', International Journal of Operations \& Production Management Vol. 28, No. 1, pp.53-78.

Sturgeon, T. and Richard, F. (2000) Globalization and Jobs in the Automotive Industry Final Report to the Alfred P. Sloan Foundation, International Motor Vehicle Program, Center for Technology, Policy, and Industrial Development, Massachusetts Institute of Technology, Cambridge, MA. Available online at: http://web.mit.edu/ipc/publications/papers.html

Sturgeon, T.J. and Lester, R.K. (2004) 'The new global supply-base: New challenges for local suppliers in East Asia' in Shahid, Y., Anjum, A.M. and Nabeshima, K. (Eds): Global Production Networking and Technological Change in East Asia, The World Bank and Oxford University Press, Washington, DC.

Sturgeon, T., Biesebroeck J.V. and Gereffi, G. (2007) Prospects for Canada in the NAFTA Automotive Industry: A Global Value Chain Analysis, Industry Canada, Research Report.

\section{Notes}

1 The entire worldwide demand for Apple's iPod digital music player, for example, is satisfied from a few final assembly plants in China owned and operated by the Taiwan Province of China-based contract manufacturer Hon Hai. These plants receive components from manufacturers located in dozens of countries in North America, Europe and Asia. In the apparel industry, GVCs are becoming consolidated in five to ten low-cost production locations, with China alone doubling its share of global apparel exports from one-sixth to nearly one-third of the total between 2000 and 2006. Larger factories and integrated 
supply-chain cities within developing economies are also becoming the norm, with footwear companies like Nike and Reebok supplying global demand from giant plants that employ 70,000 or more workers (Gereffi, 2006, pp.33-37).

2 As Yves van der Straaten, OICA Secretary-General, put it:

"Vehicle manufacturers are world leaders in research and development and spend many billions of euros every year on $R \& D$ to further improve existing concepts and to develop hybrids or alternative fuel vehicles using natural gas, biofuels, hydrogen and others .... Vehicle technology alone however cannot give the complete answer ... A pragmatic approach is needed, including also fuels and their availability, improved road infrastructure and traffic management and of course the consumer who buys and uses the product. To support this, government policies need to be clear, internationally coherent, predictable and stable."

3 Except for after-market parts production, which is included in the analysis of the automotive supply base.

4 A construction technique that supports structural integrity by using an object's external skin to support most of the load on the structure, in contrast to using an internal framework (or spaceframe) covered with a non-load-bearing skin.

5 In the electronics industry, by contrast, barriers to entry and value chain upgrading are much lower. For example, in 1984 Cisco Systems was founded by a small group of computer scientists from Stanford University to develop computer-networking hardware. By the end of 2006, Cisco had 51,480 employees, US\$28.4 billion in sales and a market capitalisation of US\$110 billion.

6 The information in this, and the other quotations presented in this paper, were collected during the course of several research projects, including the Globalisation and Jobs in the Motor Vehicle Industry Project, for which field research was conducted in 1997 and 1998 (see: http://web.mit.edu/ipc/publications/papers.html for the final report) and the Industrial Performance Center Globalisation Study, with field research conducted between 2000 and 2004 (see http://ipc-lis.mit.edu/globalization/ and Berger et al., 2005 for a summary of results). These qualitative data were collected on a confidential basis; the companies and individual managers cannot be named. The statements represent the opinion of the individual respondent and are included for illustrative purposes only. For more on the role of observational methods in economic research, see Helper (2000). 